\title{
Homocysteine thiolactone inhibits insulin signaling, and glutathione has a protective effect
}

\section{S Najib and V Sánchez-Margalet}

Department of Medical Biochemistry and Molecular Biology, School of Medicine, Investigation Unit, Virgen Macarena University Hospital, Seville, Spain

(Requests for offprints should be addressed to V Sánchez-Margalet, Department of Medical Biochemistry and Molecular Biology, School of Medicine, Investigation Unit, Virgen Macarena University Hospital, Avenue Sanchez Pizjuan 4, Seville 41009, Spain; Email: vsanchez@cica.es)

\begin{abstract}
Hyperhomocysteinemia and insulin resistance are independent factors for cardiovascular disease. Most of the angiotoxic effects of homocysteine are related to the formation of homocysteine thiolactone and the consequent increase in oxidative stress. The oxidative stress has also been shown to impair insulin action, therefore leading to insulin resistance. In order to study a putative direct effect of homocysteine on insulin signaling, we have characterized the molecular counter-regulation of the early events in the signal transduction of the insulin receptor, and the metabolic end-point of glycogen synthesis. We employed HTC rat hepatoma cells transfected with the human insulin receptor. A $10 \mathrm{~min}$ exposure to homocysteine thiolactone $(50 \mu \mathrm{M})$ resulted in a significant inhibition of insulin-stimulated tyrosine phosphorylation of the insulin receptor $\beta$-subunit and its substrates IRS-1 and $\mathrm{p} 60-70$, as well as their association with the $\mathrm{p} 85$ regulatory subunit of phosphatidylinositol 3-kinase.
\end{abstract}

These effects led to impairment of the insulinstimulated phosphatidylinositol 3-kinase activity, which plays a central role in regulating insulin action. Thus, insulin-stimulated glycogen synthesis was also inhibited by homocysteine thiolactone. To investigate whether oxidative stress was mediating the counter-regulatory effect of homocysteine thiolactone on insulin signaling, we preincubated the cells $(5 \mathrm{~min})$ with $250 \mu \mathrm{M}$ glutathione prior to the incubation with homocysteine $(10 \mathrm{~min})$ and subsequent insulin challenge. Glutathione completely abolished the effects of homocysteine thiolactone on insulin-receptor signaling and restored the insulin-stimulated glycogen synthesis. In conclusion, these data suggest that homocysteine thiolactone impairs insulin signaling by a mechanism involving oxidative stress, leading to a defect in insulin action.

Fournal of Molecular Endocrinology (2001) 27, 85-91

\section{INTRODUCTION}

Elevated plasma levels of homocysteine are an independent risk factor for atherothrombosis (Boushey et al. 1995, Kang \& Wong 1996, McCully 1996). Hereditary enzymatic deficiencies and nutritional deficiencies of folate, pyridoxine or cobalamin, as well as chronic renal failure, are associated with elevated blood homocysteine and accelerated atherosclerosis (Guttormsen et al. 1996, Jacques et al. 1996, Kang \& Wong 1996, Robinson et al. 1996). The etiological factors for atherosclerosis are believed to increase conversion of methionine to homocysteine thiolactone, the reactive cyclic internal lactone of homocysteine (McCully 1993,
Jakubowski et al. 2000). The synthesis of homocysteine thiolactone occurs in all human cell types, and increased homocysteine levels lead to elevation of thiolactone levels in human cells (Jakubowski 2000). The oxidant stress of hyperhomocystein(e)mia, partly mediated by the production of thiolactone, seems to underly the vascular dysfunction produced by homocysteine (Blundel et al. 1996, Loscalzo 1996).

Another independent risk factor for atherosclerosis is insulin resistance (Ferrannini et al. 1991, Reaven 1993), and oxidative stress is thought to be a causal link (Ceriello \& Pirisi 1995, Paolisso \& Giuliano 1996, Wittmann \& Nagy 1996). Thus, oxidative stress has been shown to reduce insulin 
action in vivo (Nourooz-Zadeh et al. 1997, De Mattia et al. 1998) and in vitro (Rudich et al. 1997, Blair et al. 1999, Khamaisi et al. 2000), as well as insulin signaling (Blair et al. 1999, Hansen et al. 1999, Tirosh et al. 1999). Since oxidative stress is supposed to mediate the homocysteine effects on atherosclerosis, the question now arises as to whether homocysteine might affect insulin signaling, thereby providing a molecular mechanism for the induction of insulin resistance. Therefore, we proposed the hypothesis that, in vitro, homocysteine thiolactone could inhibit insulin signaling by inducing oxidative stress.

Insulin is known to activate multiple signaling pathways (Cheatham \& Kahn 1995, Myers \& White 1996), but the earlier events are the activation of tyrosine kinase activity of the insulin receptor $\beta$-subunit (White et al. 1988), the tyrosine phosphorylation of its substrates (Sun et al. 1992, Sung et al. 1994, Sánchez-Margalet \& Najib 1999), and the interaction with $\mathrm{SH} 2$-domain-containing proteins, such as $\mathrm{p} 85$, the regulatory subunit of phosphatidylinositol 3-kinase (PI3K) (Sun et al. 1992, Sánchez-Margalet et al. 1995, SánchezMargalet \& Najib 1999). PI3K plays a central role in regulating glucose transport and glycogen synthesis (Sánchez-Margalet et al. 1994, SánchezMargalet 2000). In this study, we show that short-term incubation with homocysteine thiolactone inhibits insulin-receptor signaling and insulinstimulated glycogen synthesis. These effects can be prevented by the presence of glutathione, suggesting that oxidative stress might mediate the inhibition of insulin signaling and action.

\section{MATERIALS AND METHODS}

\section{Antibodies and reagents}

Monoclonal antibodies (anti-insulin receptor $(\alpha$-IR) and anti-Sam68 ( $\alpha$-Sam68) ) and polyclonal antiIRS-1 were purchased from Santa Cruz Biotechnology (Santa Cruz, CA, USA). Antiserum to the p $85 \alpha$ regulatory subunit of PI3K $(\alpha-\mathrm{p} 85)$ was from Upstate Biotechnology, Inc. (Lake Placid, NY, USA). Monoclonal antibodies to phosphotyrosine $(\alpha-P Y)$ were purchased from Transduction Laboratories (Lexington, KY, USA). Electrophoretic chemicals and molecular weight standards were from Novex (San Diego, CA, USA). Fetal calf serum, culture medium (Dulbecco's modified Eagle's medium (DMEM)) and supplements (antibiotics, glutamine) were from Biological Industries (Kibbutz Beit Haemek, Israel). Protein-A Sepharose was from Amersham Pharmacia Biotech (Barcelona, Spain). Homocysteine thiolactone was from Sigma (Alcobendas, Madrid, Spain). $\left[\mathrm{U}_{-}{ }^{14} \mathrm{C}\right]$ Glucose $(250 \mathrm{mCi} / \mathrm{mmol})$ was purchased from ICN Iberica (Barcelona, Spain).

\section{Cells and preparation of soluble cell lysates}

Rat HTC hepatoma cells overexpressing the human insulin receptor (HTC-IR) were kindly provided by Dr Ira D Goldfine (University of California, San Francisco, CA, USA). Cells were prepared and maintained in DMEM as previously described (Sánchez-Margalet et al. 1995). For experiments, cells were grown in $100 \mathrm{~mm}$ dishes to $90 \%$ confluency and serum-starved for $24 \mathrm{~h}$. They were treated for $5 \mathrm{~min}$ at $37^{\circ} \mathrm{C}$ with $100 \mathrm{nM}$ insulin, and preincubated (or not) with $50 \mu \mathrm{M}$ homocysteine thiolactone for $10 \mathrm{~min}$ prior to insulin stimulation. In some experiments, $250 \mu \mathrm{M}$ glutathione was added $5 \mathrm{~min}$ before homocysteine thiolactone preincubation. Homocysteine and glutathione were not washed before insulin stimulation, and were present during the incubation period. Cells were solubilized for $30 \mathrm{~min}$ at $4{ }^{\circ} \mathrm{C}$ in lysis buffer containing $20 \mathrm{mM}$ Tris, pH 8, 1\% Nonidet P-40, $137 \mathrm{mM} \mathrm{NaCl}, 1 \mathrm{mM}$ $\mathrm{MgCl}_{2}, 1 \mathrm{mM} \mathrm{CaCl}, 1 \mathrm{mM}$ dithiothreitol (DTT), $10 \%$ glycerol, $1 \mathrm{mM}$ phenylmethylsulfonyl fluoride and $0.4 \mathrm{mM}$ sodium orthovanadate (SánchezMargalet et al. 1995). After centrifugation, the soluble cell lysates were used for the study. The protein concentration was determined using a kit from Bio-Rad (Richmond, CA, USA), with bovine serum albumin as the standard.

\section{Immunoprecipitation and Western blotting}

Soluble cell lysates ( $2 \mathrm{mg}$ protein) were first precleared with $50 \mu \mathrm{l}$ protein A-Sepharose for $2 \mathrm{~h}$ at $4{ }^{\circ} \mathrm{C}$ and incubated with appropriate antibodies for $2 \mathrm{~h}$ at $4{ }^{\circ} \mathrm{C}$. Fifty microlitres protein A-Sepharose were then added to the antibody-containing sample and incubation was continued for $1 \mathrm{~h}$ at $4{ }^{\circ} \mathrm{C}$ (Sánchez-Margalet et al. 1995). The immunoprecipitates were washed three times with lysis buffer. Fifty microlitres SDS-stop buffer containing $100 \mathrm{mM}$ DTT were added to immunoprecipitates and then boiled for $5 \mathrm{~min}$. These were then analysed by Western blotting. Samples were resolved by SDS-PAGE and electrophoretically transferred onto nitrocellulose membranes. The membranes were blocked with Tris-buffered saline/0.05\% Tween 20 (TBST) containing 5\% non-fat dried milk for $1 \mathrm{~h}$, washed in TBST, and incubated with primary antibodies. After being washed in TBST, membranes were further incubated with secondary antibodies linked to horseradish peroxidase. Bound horseradish peroxidase was visualized by a highly 
sensitive chemiluminescence system (SuperSignal; Pierce, Rockfold, IL, USA) (Sánchez-Margalet \& Najib 1999). The bands obtained in the Western blots were scanned and then analysed by the PCBAS $2 \cdot 0$ program.

\section{PI3K activity}

PI3K activity was measured directly in antiphosphotyrosine immunoprecipitates in $50 \mu$ l of a reaction mix containing $0.2 \mathrm{mg}$ phosphatidylinositol/ml (Sigma), $20 \mathrm{mM}$ Hepes, pH 7·1, $0.4 \mathrm{mM}$ EGTA, $0.4 \mathrm{mM}$ sodium phosphate, $10 \mathrm{mM}$ $\mathrm{MgCl}_{2}$ and $\left[\gamma_{-}{ }^{32} \mathrm{P}\right] \mathrm{ATP}(40 \mu \mathrm{M}$ and $0 \cdot 1 \mu \mathrm{Ci} / \mu \mathrm{l})$ (Sung et al. 1994, González-Yanes \& SánchezMargalet 2000). After $5 \mathrm{~min}$, the reaction was stopped by the addition of $15 \mu \mathrm{l} 4 \mathrm{M} \mathrm{HCl}$ and $130 \mu \mathrm{l}$ chloroform/methanol (1:1). Twenty microliters of the lower organic layer was spotted onto a silica gel-60 plate (Merck, Darmstadt, Germany), which was preactivated with $1 \%$ potassium oxalate at $100{ }^{\circ} \mathrm{C}$ and analyzed by thin-layer chromatography in chloroform/methanol/water/ammonia (60:27:11:2 by vol.). Dried plates were then exposed to a film for 3-7 days with intensifying screens for autoradiography.

\section{Glycogen synthesis}

Serum-starved cells were treated for $10 \mathrm{~min}$ in 6 -well plates with or without $50 \mu \mathrm{M}$ homocysteine thiolactone prior to insulin stimulation $(100 \mathrm{nM})$ in Hepes-Ringer buffer containing $10 \mathrm{mM}$ glucose, and $1 \%$ bovine serum albumin. Glutathione $(250 \mu \mathrm{M})$ was added $5 \mathrm{~min}$ before homocysteine addition. After $30 \mathrm{~min}$ incubation with insulin, $\left[\mathrm{U}-{ }^{14} \mathrm{C}\right]$ glucose $(1 \mu \mathrm{Ci} /$ well $)$ was added and the incubation continued for $1 \mathrm{~h}$. Glycogen was isolated and the radioactivity counted as described previously (Sánchez-Margalet 2000).

\section{RESULTS}

\section{Homocysteine thiolactone inhibits insulin-stimulated tyrosine phosphorylation of the insulin-receptor $\beta$-subunit}

To examine the effect of homocysteine thiolactone on insulin-stimulated tyrosine autophosphorylation of insulin receptors, cells were preincubated with $50 \mu \mathrm{M}$ homocysteine thiolactone for $10 \mathrm{~min}$ prior to stimulation for $5 \mathrm{~min}$ with $100 \mathrm{nM}$ insulin. Cell lysates were subjected to SDS-PAGE and analysed by Western blotting with anti-phosphotyrosine antibodies. As shown in Fig. 1A, insulin-mediated tyrosine phosphorylation of the insulin-receptor

\section{A Cell lysate}

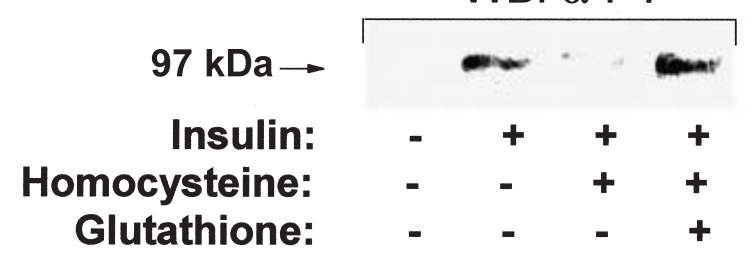

B

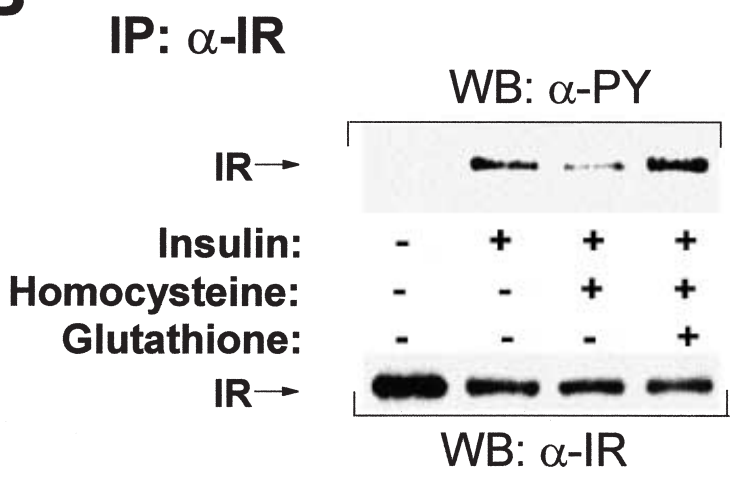

FIGURE 1. Effect of homocysteine thiolactone on insulin-mediated insulin-receptor tyrosine phosphorylation. Serum-starved HTC-IR cells were pretreated with or without $50 \mu \mathrm{M}$ homocysteine thiolactone for $10 \mathrm{~min}$ before the stimulation with or without $100 \mathrm{nM}$ insulin for $5 \mathrm{~min}$. When employed, glutathione $(250 \mu \mathrm{M})$ was added 5 min before the homocysteine. Cell lysates were subjected to SDS-PAGE and analysed by Western blotting with anti-phosphotyrosine ( $\alpha$-PY) (A). Cell lysates were also immunoprecipitated with anti-insulin-receptor $\beta$-subunit $(\alpha$-IR), subjected to SDS-PAGE, and analysed by Western blotting antibody with $\alpha-P Y(B)$. IR, insulin-receptor $\beta$-subunit; IP, immunoprecipitating antibody; WB, Western blotting antibody. The blots shown are representative of 4 experiments.

$\beta$-subunit was prevented by the preincubation with thiolactone. Next, we investigated the possible role of oxidative stress in the inhibitory effect of homocysteine thiolactone. Thus, we added $250 \mu \mathrm{M}$ glutathione $5 \mathrm{~min}$ before the preincubation with homocysteine thiolactone. As shown in Fig. 1A, glutathione restored the insulin-mediated tyrosine phosphorylation of insulin-receptor $\beta$-subunit.

To further demonstrate the effects of homocysteine thiolactone on tyrosine phosphorylation of the insulin-receptor $\beta$-subunit, we immunoprecipitated the cell lysates with anti-insulin-receptor $\beta$-subunit antibody after the incubation of the cells. Immunoprecipitates were further analyzed by Western blotting with anti-phosphotyrosine antibody. As shown in Fig. 1B, insulin-mediated 
tyrosine phosphorylation of the insulin-receptor $\beta$-subunit was impaired by the pretreatment of the cells with homocysteine thiolactone. As observed with whole-cell lysates, glutathione completely restored insulin-mediated tyrosine phosphorylation of the insulin-receptor $\beta$-subunit, as assessed by analyzing the immunoprecipitates with specific anti-phosphotyrosine immunoblotting. As a control for the amount of insulin receptor, we used a Western blot of the same samples against the insulin-receptor $\beta$-subunit.

Inhibition, by homocysteine thiolactone, of insulin-stimulated tyrosine phosphorylation of insulin-receptor substrates

Next, we investigated whether the proximal events in insulin post-receptor signaling were also affected by pretreatment with homocysteine thiolactone, i.e. by tyrosine phosphorylation of the insulin-receptor substrates. We assessed tyrosine phosphorylation of two substrates previously characterized in this hepatoma cell line, IRS-1 and Sam68, one of the p60-70 substrates of the insulin receptor (SánchezMargalet 1999, Sánchez-Margalet \& Najib 1999), by specific immunoprecipitation followed by antiphosphotyrosine immunoblotting. As shown in Fig. 2 , homocysteine thiolactone pretreatment inhibited the tyrosine phosphorylation of both substrates (IRS-1, Fig. 2A; Sam68, Fig. 2B), in parallel with the observed inhibition on the insulin-receptor $\beta$-subunit (Fig. 1). Again, as observed with the anti-insulin receptor immunoprecipitates, glutathione prevented the inhibitory effect of homocysteine thiolactone on the tyrosine phosphorylation of both substrates (IRS-1, Fig. 2A; Sam68, Fig. 2B). The amounts of immunoprecipitated substrate were checked by specific Western blotting of the same samples with either anti-IRS-1 (Fig. 2A), or anti-Sam68 (Fig. 2B).

\section{Homocysteine thiolactone inhibits the association of the insulin-receptor $\beta$-subunit and its substrates with $\mathrm{p85}$, the regulatory subunit of PI3K}

To clarify the inhibition of insulin-receptor signaling produced by homocysteine thiolactone, we assessed the insulin-mediated association of tyrosine-phosphorylated proteins with p85, the regulatory subunit of PI3K. We had previously characterized the tyrosine-phosphorylated proteins associated with p85 in these cells in response to insulin: the insulin-receptor $\beta$-subunit, IRS-1, and p60-70 substrates (Sánchez-Margalet et al. 1995, Sánchez-Margalet \& Najib 1999). As shown in

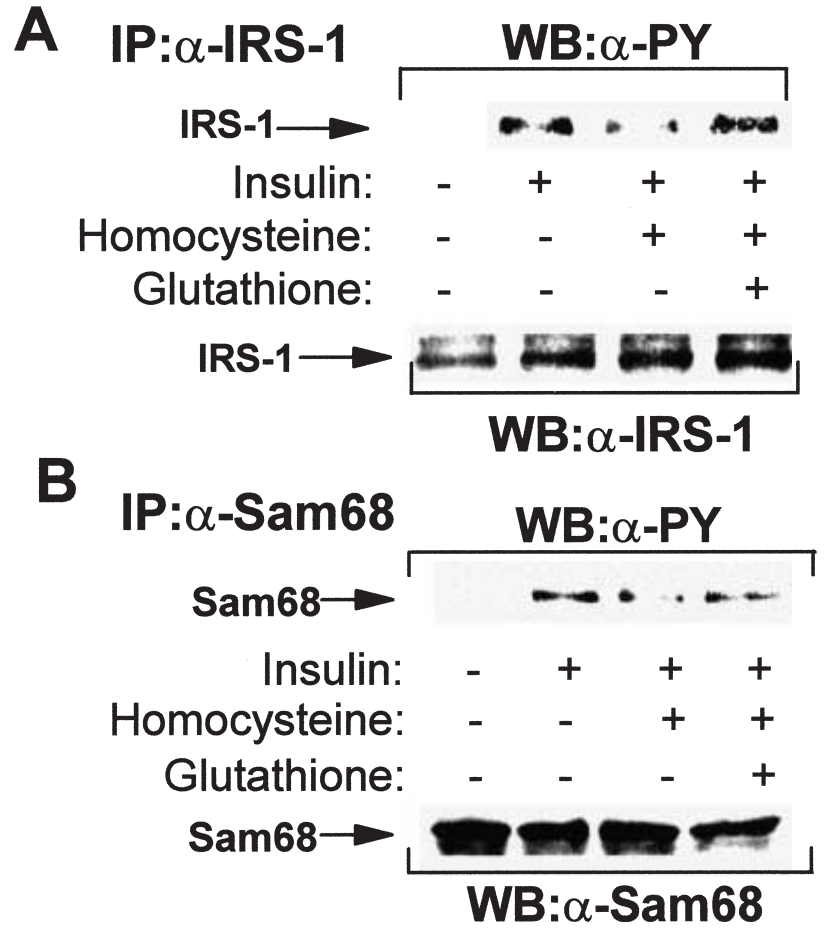

FIGURE 2. Effect of homocysteine thiolactone on insulininduced tyrosine phosphorylation of insulin-receptor substrates. Serum-starved HTC-IR cells were treated as described in the legend to Fig. 1. Solubilized cell lysates were immunoprecipitated with anti-IRS-1 ( $\alpha$-IRS-1) (A), or anti-Sam68 ( $\alpha$-Sam68) (B), subjected to SDS-PAGE, and analysed by Western blotting with $\alpha$-PY. The same samples were analysed with anti-IRS-1 (A) or antiSam68 (B) to check the amount of immunoprecipitated protein. IP, immunoprecipitating antibody; WB, Western blotting antibody. Similar results were obtained in 3 other experiments.

Fig. 3, homocysteine thiolactone impaired the association of the insulin-stimulated tyrosinephosphorylated proteins with p85, and, again, glutathione prevented this inhibitory effect of homocysteine. The amount of immunoprecipitated p85 was similar in every sample, as assessed using anti-p85 immunoblotting (Fig. 3).

\section{Inhibition by homocysteine thiolactone of phosphatidylinositol 3-kinase activity}

Next, we studied the effect of homocysteine thiolactone on PI3K activity. To check whether the thiolactone inhibition of tyrosine phosphorylation of the insulin receptor and substrates and their association with $\mathrm{p} 85$-PI3 $\mathrm{K}$ led to changes in the activity, we measured PI3K activity in antiphosphotyrosine immunoprecipitates. As shown in Fig. 4, phosphotyrosine-associated PI3K activity 
IP: $\alpha-p 85-P I K$

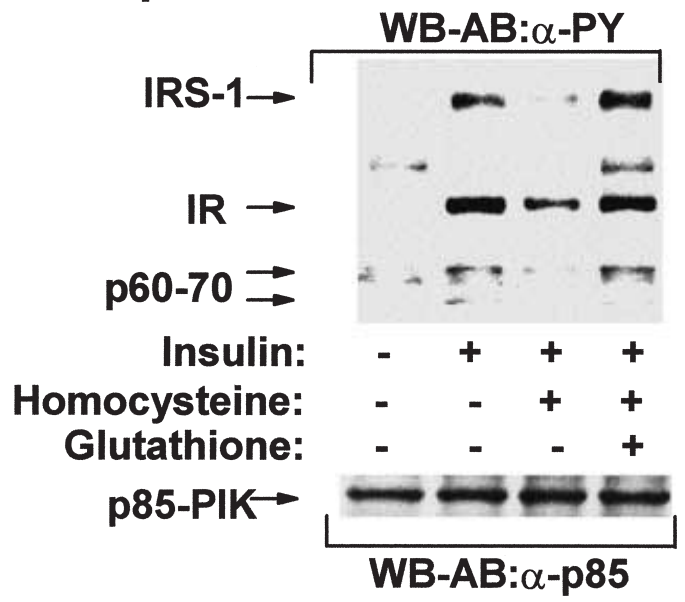

FIGURE 3. Effect of homocysteine thiolactone on the association of tyrosine-phosphorylated proteins with $\mathrm{p} 85$, the regulatory subunit of PI3K. Cells were treated as described in the legend to Fig. 1. Solubilized cell lysates were immunoprecipitated with anti-p85 PI3K $(\alpha-\mathrm{p} 85$-PIK), subjected to SDS-PAGE, and analysed by Western blotting with $\alpha-\mathrm{PY}$. IR, insulin receptor $\beta$-subunit; IRS-1, insulin-receptor substrate-1; p60-70, 60-70 kDa insulin-receptor substrate; IP, immunoprecipitating antibody; WB-AB, Western blotting antibody. The experiment shown is representative of three others.

was stimulated by $100 \mathrm{nM}$ insulin, and $50 \mu \mathrm{M}$ homocysteine thiolactone prevented this effect of insulin. In parallel with the phosphorylation data, glutathione $(250 \mu \mathrm{M})$ was able to block the inhibitory effect of homocysteine thiolactone on isulin-stimulated PI3K activity (Fig. 4).

\section{Homocysteine thiolactone inhibits insulin-stimulated glycogen synthesis}

To investigate the effect of homocysteine thiolactone on the metabolic end-point of the PI3K pathway, i.e. glycogen synthesis (Sánchez-Margalet 2000), we measured glucose incorporation into glycogen, by using $\left[\mathrm{U}_{-}{ }^{14} \mathrm{C}\right]$ glucose. As shown in Fig. 5, $50 \mu \mathrm{M}$ homocysteine thiolactone completely blocked the metabolic effect of insulin on glycogen synthesis in HTC hepatoma cells. This inhibitory effect of homocysteine thiolactone was fully prevented by the preincubation of cells with glutathione $(250 \mu \mathrm{M})$ prior to the addition of homocysteine.

\section{DISCUSSION}

In this study, we demonstrate that short-term treatment of HTC-IR cells with micromolar

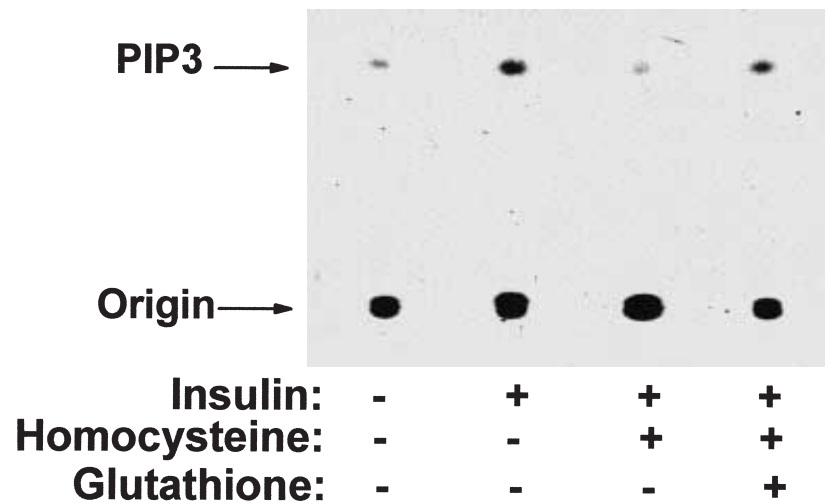

FIGURE 4. Effect of homocysteine thiolactone on phosphotyrosine-associated PI3K activity phosphatidyl inositol-3-phosphate (PIP3) is the product of PI3K activity. Serum-starved HTC-IR cells were treated as described in the legend to Fig. 1. Solubilized cell lysates were immunoprecipitated with $\alpha-\mathrm{PY}$, and immunoprecipitates were then used to determine PI3K activity. Samples were chromatographed by thin-layer chromatography. The autoradiogram shown is representative of three.

concentrations of homocysteine thiolactone $(50 \mu \mathrm{M})$ inhibits insulin signaling, leading to an inhibitory effect on insulin-stimulated glycogen synthesis. Thus, we present data on the inhibition of insulin-receptor kinase, as well as on downstream signaling events such as the tyrosine phosphorylation of insulin-receptor substrates, their association
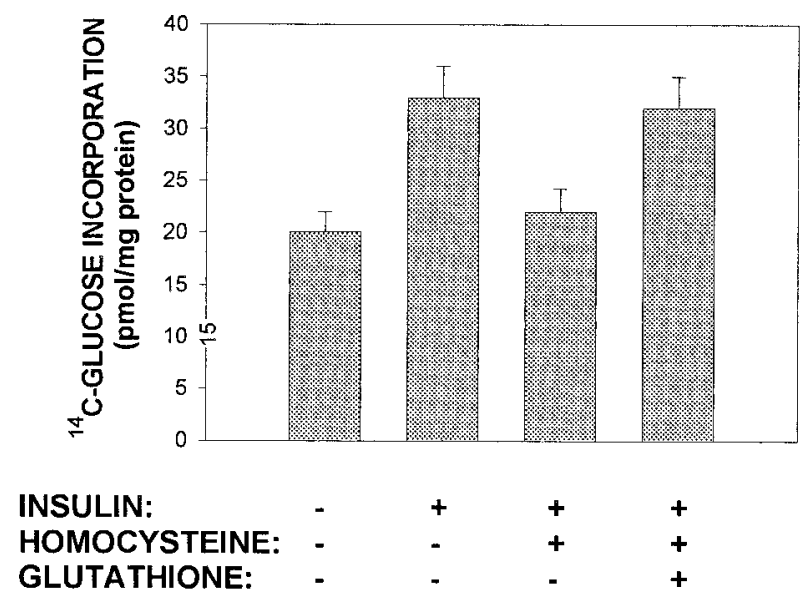

FIGURE 5. Effect of homocysteine thiolactone on insulin-stimulated glycogen synthesis. Cells were treated as described in the legend for Fig. 1, but insulin $(100 \mathrm{nM})$ stimulation was extended for $30 \mathrm{~min}$. $\left[\mathrm{U}-{ }^{14} \mathrm{C}\right]$ Glucose $(1 \mu \mathrm{Ci} /$ well $)$ was then added to the cells and the incubation continued for $1 \mathrm{~h}$ to determine glucose incorporation into glycogen. The data shown are means \pm s.E.M. of four separate experiments. 
with p85-PI3K and PI3K activation, one of the major signaling cascades that plays a central role in the regulation of insulin action (Kahn 1994, Cheatham et al. 1994, Sánchez-Margalet et al. 1994, Sánchez-Margalet 2000). Since the PI3K signaling pathway is dependent on the tyrosine kinase activity of the insulin receptor and the tyrosine phosphorylation of its substrates, the inhibition of PI3K by homocysteine thiolactone may be attributed to defects in the early events of the insulin signaling. A further direct effect of thiolactone on downstream signaling events, such as PI3K activity, cannot be ruled out, however. In fact, the inhibition of PI3K seems stronger than the inhibition observed with tyrosine phosphorylation. Therefore, a multi-step inhibitory effect of homocysteine thiolactone may not be striking. In any case, the major metabolic end-point of the PI3K pathway, i.e. the insulinstimulated glycogen synthesis (Sánchez-Margalet 2000), is almost completely inhibited by homocysteine thiolactone. Thus, the deleterious effects of homocysteine in insulin signaling translates to an inhibition of insulin action, at least in the context of glycogen synthesis.

Protein homocysteinylation by homocysteine thiolactone, resulting in protein damage, is one of the mechanisms underlying the involvement of homocysteine in the pathology of vascular disease (Jakubowski 1997, 2000). In the light of the present study, such a mechanism is unlikely to mediate the effects of thiolactone on insulin-receptor signaling, since these effects are observed after a short period of treatment. Nevertheless, longer exposures of cells to homocysteine thiolactone might contribute to the protein modification, damage, multimerization and precipitation of molecules of the insulin signaling cascade, leading to a decrease in the amount of functional protein. Consistently, we have not observed any differences in the amounts of signaling proteins under our short-term experimental conditions.

On the other hand, we have observed that glutathione $(250 \mu \mathrm{M})$ completely blocked the inhibitory effect of homocysteine thiolactone on insulin signaling and action. Thus, the thiolactone impairment in the autophosphorylation of the insulin receptor, the tyrosine phosphorylation of its substrates, their association with $\mathrm{p} 85-\mathrm{PI} 3 \mathrm{~K}$, and the PI3K activity itself, as well as the insulinstimulation of glycogen synthesis, are completely restored by glutathione. These results strongly suggest that the mechanism underlying the defects in insulin signaling involves the oxidative stress produced by homocysteine thiolactone. In this context, the inhibition of insulin signaling could be another oxidation-mediated toxic effect on liver cells, in addition to the toxic effects reported for endothelial cells in culture (de Groot et al. 1983, Starkebaum \& Harlam 1986, Stamler et al. 1993). On the other hand, we have ruled out the possibility that the effect of homocysteine thiolactone on insulin signaling and action is mediated by the inhibition of insulin binding (data not shown). Rather, the effects may be exerted intracellularly in the insulin-receptor activation and the downstream signaling pathways. In fact, the inhibitory effect of oxidative stress on insulin signaling has been studied previously (Blair et al. 1999, Hansen et al. 1999, Tirosh et al. 1999), as well as the inhibition of insulin action by oxidative stress or the inhibition of glutathione synthesis (Rudich et al. 1997, Blair et al. 1999, Khamaisi et al. 2000). Moreover, infusion of reduced glutathione has been shown to improve insulin sensitivity in type 2 diabetic patients (De Mattia et al. 1998).

In summary, these results lead to the conclusion that homocysteine thiolactone inhibits insulin signaling and action by a mechanism involving oxidative stress. Therefore, an effect of homocysteine on insulin resistance in vivo might be expected. Thus, homocysteine could be a new factor that functions as a relevant mediator of oxidative stress-induced insulin resistance. This hypothesis remains to be studied, but the data presented here give some clue as to the intracellular mechanisms by which homocysteine may eventually lead to insulin resistance.

\section{ACKNOWLEDGEMENTS}

This work was supported by a grant from the Fondo de Investigación Sanitaria (FIS 00/0311), Ministerio de Sanidad, Spain and SAS 7/00, Junta de Andalucia, Spain.

\section{REFERENCES}

Blair AS, Hajduch E, Litherland GJ \& Hundal HS 1999 Regulation of glucose transport and glycogen synthesis in L6 muscle cells during oxidative stress. Evidence for cross-talk between the insulin and SAPK2/p38 mitogen-activated protein kinase signaling pathways. Fournal of Biological Chemistry 274 36293-36299.

Blundell G, Jones BG, Rose FA \& Tudball N 1996

Homocysteine mediated endothelial cell toxicity and its amelioration. Atherosclerosis 122 163-172.

Boushey CJ, Beresford SA, Omen GS \& Motulsky AG 1995 A quantitative assessment of plasma homocysteine as a risk factor for vascular disease. Probable benefits of increasing folic acid intakes. Fournal of the American Medical Association 274 1049-1057.

Ceriello A \& Pirisi M 1995 Is oxidative stress the missing link between insulin resistance and atherosclerosis? Diabetologia 38 1484-1485.

Cheatham B \& Kahn CR 1995 Insulin action and the insulin signaling network. Endocrine Reviews 16 117-142. 
Cheatham B, Vlahos C, Cheatham L, Wang L, Blenis J \& Kahn CR 1994 Phosphatidylinositol 3-kinase activation is required for insulin stimulation of pp70 S6 kinase, DNA synthesis, and glucose transporter translocation. Molecular and Cellular Biology 14 4902-4911.

De Mattia G, Bravi MC, Laurenti O, Cassone-Faldetta M, Armiento A, Ferri C \& Balsano F 1998 Influence of reduced glutathione infusion on glucose metabolism in patients with non-insulin-dependent diabetes mellitus. Metabolism $\mathbf{4 7}$ 993-997.

Ferrannini E, Haffner SM, Mitchel BD \& Stern MP 1991 Hyperinsulinemia: the key feature of a cardiovascular and metabolic subject. Metabolism 47 686-689.

González-Yanes C \& Sánchez-Margalet V 2000 Pancreastatin modulates insulin signaling in rat adipocytes. Mechanisms of cross-talk. Diabetes 49 1288-1294.

de Groot PG, Willems C, Boers GHJ, Gonsalves MD, van Aken WG \& van Mourik JA 1983 Endothelial cell dysfunction in homocystinuria. European Fournal of Investigation 13 405-410.

Guttormsen AB, Ueland PM, Nesthus I, Nygard O, Schneede J, Vollset SE \& Refsum H 1996 Determinants and vitamin responsiveness of intermediate hyperhomocysteinemia (>or $=40$ micromol/liter). The Hordaland Homocysteine Study. Fournal of Clinical Investigation 98 2174-2183.

Hansen LL, Ikeda Y, Olsen GS, Busch A \& Mosthaf L 1999 Insulin signaling is inhibited by micromolar concentrations of $\mathrm{H}(2) \mathrm{O}(2)$. Evidence for a role of $\mathrm{H}(2) \mathrm{O}(2)$ in tumor necrosis factor alpha-mediated insulin resistance. Fournal of Biological Chemistry 274 25078-25084.

Jacques PF, Bostom AG, Williams RR, Ellison RC, Eckfeldt JH, Rosenberg IH, Sehub J \& Rozen R 1996 Relation between folate status, a common mutation in methylenetetrahydrofolate reductase, and plasma homocysteine concentrations. Circulation 93 7-9.

Jakubowski H 1997 Metabolism of homocysteine thiolactone in human cell cultures. Possible mechanism for pathological consequences of elevated homocysteine levels. Fournal of Biological Chemistry 272 1935-1942.

Jakubowski H 2000 Homocysteine thiolactone: metabolic origin and protein homocysteinylation. Fournal of Nutrition 130 (Suppl 2S) S377-S381.

Jakubowski H, Zhang L, Bardeguez A \& Aviv A 2000 Homocysteine thiolactone and protein homocysteinylation in human endothelial cells: implications for atherosclerosis. Circulation Research 87 45-51.

Kahn CR 1994 Insulin action, diabetogenes, and the cause of type II diabetes. Diabetes 43 1066-1084.

Kang SS \& Wong PW 1996 Genetic and nongenetic factors for moderate hyperhomocyst(e)inemia. Atherosclerosis 119 $135-138$.

Khamaisi M, Kavel O, Rosenstock M, Porat M, Yuli M, Kaiser N \& Rudich A 2000 Effect of glutathione synthesis on insulin action: in vivo and in vitro studies using buthioninesulfoximine. Biochemical fournal 349 579-586.

Loscalzo J 1996 The oxidant stress of hyperhomocyst(e)inemia. Fournal of Clinical Investigation 98 5-7.

McCully KS 1993 Chemical pathology of homocysteine. Annals of Clinical and Laboratory Science 23 477-493.

McCully KS 1996 Homocysteine and vascular disease. Nature Medicine 2 386-389.

Myers MG \& White MF 1996 Insulin signal transduction and the IRS proteins. Annual Review of Pharmacology and Toxicology 36 615-658.

Nourooz-Zadeh J, Rahimi A, Tajaddini-Sarmadi J, Tritschler H, Rosen P, Halliwell B \& Betteridge DJ 1997 Relationship between plasma measures of oxidative stress and metabolic control in NIDDM. Diabetologia 40 647-653.
Paolisso G \& Giuliano D 1996 Oxidative stress and insulin action: is there a relationship? Diabetologia $39357-363$.

Reaven GM 1993 Role of insulin resistance in human disease (syndrome X): an expanded definition. Annual Review of Medicine 44 121-131.

Robinson K, Gupta A, Dennis VW, Arheart K, Chaudhary D, Green R, Vigo P, Mayer EL, Selhub J, Kutner M \& Jacobsen D 1996 Hyperhomocysteinemia confers an independent increased risk of atherosclerosis in endstage renal disease and is closely linked to plasma folate and pyridoxine concentrations. Circulation 94 2743-2748.

Rudich A, Kozlovsky N, Potashnik R \& Bashan N 1997 Oxidant stress reduces insulin responsiveness in 3T3-L1 adipocytes. American Fournal of Physiology 272 E935-E940.

Sánchez-Margalet V 1999 Modulation of insulin receptor signaling by pancreastatin. Diabetologia 42 317-325.

Sánchez-Margalet V 2000 Stimulation of glycogen synthesis by insulin requires $\mathrm{S} 6$ kinase and phosphatidylinositol-3-kinase in HTC-IR cells. Fournal of Cellular Physiology 182 182-188.

Sánchez-Margalet V \& Najib S 1999 p68 Sam is a substrate of the insulin receptor and associates with the $\mathrm{SH} 2$ domains of p85 PI3K. FEBS Letters 455 307-310.

Sánchez-Margalet V, Goldfine ID, Vlahos C \& Sung CK 1994 Role of phosphatidylinositol-3-kinase in insulin receptor signaling: studies with inhibitor LY294002. Biochemical and Biophysical Research Communications 204 446-452.

Sánchez-Margalet V, Goldfine ID, Truitt K, Imboden J \& Sung CK 1995 Role of p85 subunit of phosphatidylinositol 3-kinase as an adaptor molecule linking the insulin receptor to insulin receptor substrate 1. Molecular Endocrinology 9 $435-442$.

Stamler JS, Osborne JA, Jaraki O, Rabbani LE, Mullins M, Singel D \& Loscalzo J 1993 Adverse vascular effects of homocysteine are modulated by endothelium-derived relaxing factor and related oxides of nitrogen. Fournal of Clinical Investigation 91 308-318.

Starkebaum G \& Harlan JM 1986 Endothelial cell injury due to copper-catalyzed hydrogen peroxide generation from homocysteine. Fournal of Clinical Investigation 77 1370-1376.

Sun XJ, Miralpeix M, Myers MG Jr, Glasheen EM, Backer JM, Kahn CR \& White MF 1992 Expression and function of IRS-1 in insulin signal transmission. Fournal of Biological Chemistry $26722662-22672$.

Sung CK, Sanchez-Margalet V \& Goldfine ID 1994 Role of p85 subunit of phosphatidylinositol-3-kinase as an adaptor molecule linking the insulin receptor, p62, and GTPaseactivating protein. Fournal of Biological Chemistry 269 12503-12507.

Tirosh A, Potashnik R, Bashan N \& Rudich A 1999 Oxidative stress disrupts insulin-induced cellular redistribution of insulin receptor substrate-1 and phosphatidylinositol 3-kinase in 3T3-L1 adipocytes. A putative cellular mechanism for impaired protein kinase B activation and GLUT4 translocation. Fournal of Biological Chemistry 274 10595-10602

White MF, Shoelson SE, Kentmann N \& Kahn CR 1988 Cascade of tyrosine autophosphorylation in the $\beta$-subunit activates the insulin receptor. Fournal of Biological Chemistry 263 2969-2980.

Wittmann I \& Nagy J 1996 Are insulin resistance and atherosclerosis the consequences of oxidative stress? Diabetologia 39 1002-1003.

RECEIVED IN FINAL FORM 4 April 2001 ACCEPTED 11 April 2001 